\title{
Perlindungan Hukum Bagi Perempuan Korban Kekerasan Nonfisik Dalam Rumah Tangga Menurut UU No. 23 Tahun 2004 di DKI Jakarta
}

\author{
Wenny Juliani \\ (Mahasiswa Program S1 Fakultas Hukum Universitas Tarumanagara) \\ (E-mail: wenny.juliani@ymail.com ) \\ Dr. Aji Wibowo, S.H., M.H. \\ (Corresponding Author) \\ (Dosen Fakultas Hukum Universitas Tarumanagara. Meraih Sarjana Hukum pada Fakultas Hukum \\ UniversitasTrisakti, Magister Hukum pada Fakultas Hukum Universitas Tarumanagara, Doktor (Dr.) \\ pada Fakultas Hukum Universitas Padjajaran) \\ (E-mail: ajilibero@yahoo.com)
}

\begin{abstract}
The Act Num. 23/2004 about the Abolition of Domestic Violence regulates about the provision of protection and restoration for victims, which are the must given to fullfil the victims' right, and also the criminal sanctions for perpetrators. According to the Act, this kind of violence divided into four categories, There are physical abuse, psychic abuse, sexual abuse and household neglection. By taking some data about violence against women in Jakarta, the problems formulation for this journal are: What the form of legal protection for women victims of non-physical violence in the household according to the Act Num. 23/2004 in Jakarta; and how the implementation of the legal protection for women victims of non-physical violence in the household according to the Act Num. 23/2004 in Jakarta. The method that used to write this journal is normative legal research, which is supported by some interviews with parties who do work in the field of fulfilling women's welfare and rights. In the act Num. 23/2004 there are two types of protection, they're temporary protection and protection based on court stipulations. On the implementation, from the very first time that the protection given until the recovery, each process involves professionals in their respective fields. It is important, so that the victim can get the immidiate and right treatment. However, the implementation of the provision of protection and restoration to the victims still faces various obstacles, both in terms of substance, structure, and culture of the community.
\end{abstract}

Keywords: Domestic violence, Protection and restoration, Implementation.

\section{Pendahuluan}

\section{A. Latar Belakang}

Perkawinan merupakan suatu ikatan yang luhur antara suami dan istri. Adapun perkawinan bertujuan untuk melanjutkan generasi penerus keluarga. 
Keluarga/rumah tangga merupakan unit terkecil dalam masyarakat yang memiliki peran dalam proses pergaulan dan interaksi. ${ }^{1}$ Proses pergaulan dan interaksi tersebut juga berpengaruh dalam pembentukkan karakter seseorang. Dalam mencapai keharmonisan dan kelanggengan dalam kehidupan berkeluarga/berumah tangga tentunya bukan persoalan yang mudah, mengingat dalam perkawinan pun tentunya terjadi berbagai persoalan, maka diperlukan sikap dan pemikiran yang matang untuk mengatasinya. Seringkali, pertengkaran kecil berujung pada pertengkaran besar, yang akhirnya tidak menutup kemungkinan terjadi kekerasan ketika kata-kata tidak dapat lagi berbicara. Hal inilah yang kita sebut dengan Kekerasan Dalam Rumah Tangga (selanjutnya disebut KDRT).

Pasal 1 UU No. 23 Tahun 2004 tentang Penghapusan Kekerasan Dalam Rumah Tangga (selanjutnya disebut UUPKDRT), menyatakan bahwa Kekerasan Dalam Rumah Tangga adalah setiap perbuatan terhadap seseorang, terutama perempuan, yang berakibat timbulnya kesengsaraan atau penderitaan secara fisik, seksual, psikologis, dan/atau penelantaran rumah tangga, termasuk ancaman untuk melakukan perbuatan, pemaksaan, atau perampasan kemerdekaan secara melawan hukum dalam lingkup rumah tangga. KDRT termasuk dalam lingkup domestic violence. Pada kenyataannya, KDRT bukan suatu hal baru yang kita temui dalam masyarakat, melainkan sudah menjadi "penyakit" yang sulit untuk dihilangkan. KDRT dapat terjadi pada siapapun dan kapanpun, tanpa memandang status sosial dan pendidikan.

Pasal 5 UUPKDRT membagi tindak KDRT dalam berbagai jenis, yaitu kekerasan fisik, kekerasan psikis, kekerasan seksual, dan penelantaran rumah tangga. Adapun yang termasuk dalam kekerasan nonfisik adalah kekerasan psikis dan penelantaran rumah tangga. Pasal 7 UUPKDRT menyatakan bahwa kekerasan psikis adalah setiap perbuatan yang mengakibatkan ketakutan, hilangnya rasa percaya diri,

\footnotetext{
${ }^{1}$ Soerjono Soekanto, Sosiologi Keluarga Tentang Ikhwal Keluarga, Remaja dan Anak, (Jakarta: Rineka Cipta, 2009), hal. 1.
} 
hilangnya kemampuan untuk bertindak, rasa tidak berdaya, dan/atau penderitaan psikis berat pada seseorang. Sedangkan, Pasal 9 UUPKDRT menyatakan bahwa setiap orang dilarang untuk menelantarkan orang dalam lingkup rumah tangganya, yang padahal menurut hukum yang berlaku baginya atau karena persetujuan atau karena perjanjian ia wajib memberikan kehidupan, perawatan, atau pemeliharaan kepada orang tersebut. Penelantaran juga berlaku bagi setiap orang yang mengakibatkan ketergantungan ekonomi dengan cara membatasi dan/atau melarang untuk bekerja yang layak di dalam atau di luar rumah, sehingga korban berada di bawah kendali orang tersebut.

Kekerasan terhadap seseorang umumnya terjadi karena berbagai faktor dan permasalahan, akan tetapi kejahatan terhadap jenis kelamin tertentu terjadi karena adanya ketimpangan terhadap jenis kelamin tersebut, atau yang biasa kita sebut dengan bias gender, sehingga muncullah apa yang dinamakan dengan gender related violence. Gender adalah pembagian peran antara laki-laki dan perempuan yang dikonstruksikan oleh masyarakat, baik melalui tradisi, kebiasaan, pola asuh anak, maupun pendidikan, yang akhirnya membedakan tugas dan peran sosial antara lakilaki dan perempuan. Tindak KDRT pada umumnya terjadi sebagai manifestasi dari ketimpangan posisi laki-laki dan perempuan dalam keluarga. ${ }^{2}$ Sesungguhnya, dalam kasus KDRT terdapat siklus yang menyebabkan kekerasan tersebut selalu terulang, bahkan dalam jangka waktu yang lama. Teori terkait siklus ini dikembangkan oleh Walker, yang terdiri dalam tiga tahap/fase utama, antara lain: ${ }^{3}$

a. Tahap pembentukan ketegangan (tension): dalam tahap ini terjadi ketegangan antara kedua belah pihak, dimana terkadang di antara para pihak tersebut masih terdapat pemikiran yang rasional, sehingga seringkali luapan-luapan emosi yang terjadi tersebut diupayakan sedemikian rupa untuk diminimalisir.

\footnotetext{
${ }^{2}$ Nur Rochaety, "Menegakkan HAM Melalui Perlindungan Hukum Bagi Perempuan Korban Kekerasan Di Indonesia”, Jurnal Studi Gender PALASTREN, Vol. 7 No. 1 (Juni 2014): 9.

${ }^{3}$ Mark Constanzo, Aplikasi Psikologi Dalam Sistem Hukum, (Yogyakarta: Pustaka Pelajar, 2006), hal. 126-132.
} 
Dalam tahap ini, istri yang bersitegang dengan suaminya, mencoba untuk melindungi dirinya dan berusaha membangun pengendalian terhadap situasi yang dialaminya, dengan menunjukkan sifat selalu mengalah atau tidak menunjukkan rasa marah.

b. Tahap tindakan kekerasan (building-battering): dalam tahap ini, ketegangan mulai mencapai puncaknya dengan dilakukannya tindak kekerasan. Hal ini terwujud dalam bentuk marah secara verbal, terjadinya penganiayaan fisik, dan/atau perkosaan (kekerasan fisik dan nonfisik).

c. Tahap memperbaiki ketegangan dengan bulan madu (concrition): dalam tahap ini, suasana dalam keluarga/rumah tangga akan kembali tenang, harmonis, manis, dan penuh dengan kemesraan. Pelaku tindak kekerasan akan mulai menunjukkan rasa penyesalan dan meminta maaf kepada pasangannya. Pelaku biasanya akan lebih perhatian, lebih menyayangi, dan lebih bijaksana. Dalam tahap ini, korban dengan harapan-harapannya mencoba untuk memaafkan pelaku, bahkan mungkin sambil terus menyalahkan dirinya sendiri. Akan tetapi, tahap ini tidak bertahan terus menerus, ketika terjadi lagi konflik, maka ketegangan akan meledak lagi dalam bentuk kekerasan.

Melihat pada kenyataan di masyarakat, yang seringkali menjadi korban KDRT adalah istri. Namun, dalam UUPKDRT lingkup perempuan menjadi beberapa subjek, yaitu istri, anak dan juga pekerja rumah tangga (selanjutnya disebut PRT). Posisi perempuan yang rentan menjadi korban disebabkan karena berbagai hal. Mulai dari fisiknya yang lebih lemah daripada laki-laki, sehingga tidak mampu membalas kekerasan yang dialaminya; istri yang begitu bergantung pada suami, sehingga seolah membiarkan kekerasan itu terjadi; hingga budaya patriarki yang masih terus mengakar dan meluas dalam masyarakat Indonesia, yang akhirnya menjadikan lakilaki sebagai sosok sentral yang harus dujunjung tinggi dalam keluarga. Terlepas dari kepribadian perempuan yang lemah, faktor determinan yang menyebabkan terjadinya tindak kekerasan terhadap perempuan sangatlah kompleks, karena adanya kombinasi 
dan interaksi dari berbagai faktor, seperti faktor biologis, psikologis, sosial, serta ekonomi dan politis, seperti riwayat kekerasan, kemiskinan, dsb. ${ }^{4}$

Tindak KDRT yang seharusnya mendapatkan perhatian dan penanganan yang lebih memadai adalah KDRT dalam bentuk kekerasan nonfisik. Tidak seperti halnya kekerasan fisik, KDRT dengan kekerasan nonfisik tidak menimbulkan bekas yang kasat mata, sehingga sulit terdeteksi, bila tidak melalui serangkaian pemeriksaan lebih lanjut. Seringkali, KDRT nonfisik dianggap remeh, karena tidak menimbulkan luka atau cacat yang serius secara kasat mata. Nyatanya, KDRT nonfisik yang berupa kekerasan psikis dan penelantaran rumah tangga akan tetap memberikan efek/dampak bagi korban, terlebih secara psikologis dan finansial. Bagi korban yang seringkali direndahkan, dihina, dilecehkan, tentunya akan membawa pengaruh pada kondisi psikisnya. Tindakan tersebut dapat membuat korban merasa rendah diri, merasa tidak berguna, bahkan pada tahap yang lebih gawat, akan menyebabkan depresi. Penelantaran dan hambatan secara finansial pun akan membuat korban tidak mampu memenuhi kebutuhan hidupnya, bahkan sampai hal yang mendasar sekalipun. Akan tetapi, dalam melihat suatu peristiwa KDRT, suatu kekerasan tidak mungkin berdiri sendiri. Seperti halnya dalam penelantaran, tentunya akan tetap mempengaruhi psikis korban, juga dengan kekerasan fisik dan seksual. Jadi, tindak KDRT bukanlah kekerasan tunggal.

Pemerintah sendiri sebenarnya sudah mulai menaruh perhatian dan memberi dukungan bagi perempuan yang menjadi korban kekerasan dalam lingkup rumah tangga, dengan membentuk UUPKDRT. Dengan adanya UUPKDRT, membuktikan bahwa negara sudah aware dalam memperhatikan dan memberikan kesejahteraan bagi perempuan dalam lingkup rumah tangga, dengan mencegah tindak KDRT, menindak pelaku KDRT, serta memberikan perlindungan dan pemulihan yang memadai bagi korban. Selain UUPKDRT, upaya nyata lainnya yang dilakukan

${ }^{4}$ Siti Homzah MS, et. al., Kekerasan Terhadap Perempuan (Tinjauan Dalam Berbagai Disiplin Ilmu dan Kasus Kekerasan), (Bandung: PT. Refika Aditama, 2010), hal. 64. 
pemerintah adalah dengan membentuk berbagai lembaga independen yang bergerak dalam bidang pemberdayaan dan pemenuhan hak-hak perempuan. Lembaga tersebutlah yang kemudian menjadi pelaksana dari pemberian perlindungan dan pemulihan bagi korban, sebagaimana yang diamanatkan oleh UUPKDRT.

Dalam menangani dan menyelesaikan persoalan KDRT, tentunya harus tetap memperhatikan hak-hak korban. Perlindungan dan pemulihan juga harus diberikan, sebagai upaya pemenuhan hak korban. Perlindungan dan pemulihan tersebut harus diberikan dengan cermat dan teliti, mengingat korban sudah banyak menderita karena berbagai kejadian tidak menyenangkan yang dialaminya. Pemerintah harus menaruh perhatian secara lebih mendalam, serta berupaya keras dalam mencegah dan menanggulangi fenomena KDRT, agar perempuan-perempuan di Indonesia dapat memperoleh dan mempertahankan hak-haknya sebagaimana mestinya, baik dalam kehidupan berkeluarga, maupun dalam kehidupan bermasyarakat.

\section{B. Permasalahan}

1. Bagaimana bentuk perlindungan hukum bagi perempuan korban kekerasan nonfisik dalam rumah tangga menurut UU No. 23 Tahun 2004 di DKI Jakarta?

2. Bagaimana pelaksanaan perlindungan hukum bagi perempuan korban kekerasan nonfisik dalam rumah tangga menurut UU No. 23 Tahun 2004 di DKI Jakarta?

\section{Metode Penelitian}

Dalam menyusun penulisan ini, digunakan metode penelitian hukum normatif, yang karakteristik utamanya adalah sumber utama berupa bahan hukum, yaitu dengan mengkaji bahan hukum yang berupa aturan yang bersifat normatif, berupa bahan pustaka atau data sekunder. ${ }^{5}$

${ }^{5}$ Soerjono Soekanto dan Sri Mamudji, Penelitian Hukum Normatif (Suatu Tinjauan Singkat), (Jakarta: Rajawali Pers, 2006), hal. 6. 


\section{Pembahasan}

\section{A. Perlindungan Hukum Bagi Perempuan Korban Kekerasan Nonfisik}

\section{Dalam Rumah Tangga Menurut UU No. 23 Tahun 2004 Di DKI Jakarta}

Perempuan memang merupakan pihak yang rentan menjadi korban, tak terkecuali dalam lingkup keluarga/rumah tangga. Hal ini membuktikan bahwa dalam lingkup keluarga/rumah tangga sekalipun, tidak menjamin akan tercipta keamanan dan kedamaian. Salah satu hal yang penting dari UUPKDRT adalah subjek yang dilindungi. Subjek yang termasuk dalam lingkup rumah tangga menurut UUPKDRT antara lain: ${ }^{6}$

1. Suami, istri dan anak;

2. Orang-orang yang mempunyai hubungan keluarga dan dengan orang sebagaimana dimaksud pada angka 1 karena hubungan darah, perkawinan, persusuan, pengasuhan, dan perwalian, yang menetap dalam rumah tangga; dan/atau

3. Orang yang bekerja membantu rumah tangga dan menetap dalam rumah tangga tersebut.

Meskipun pada kenyataannya, yang seringkali menjadi korban KDRT dalam masyarakat adalah istri, namun dengan adanya subjek lain yang ikut serta diatur perlindungannya dalam UUPKDRT, menandakan bahwa dalam pembentukkannya, UUPKDRT benar-benar dipersiapkan dengan matang dan cermat, agar dapat menjangkau dan mewujudkan keadilan dan kesetaraan gender bagi siapapun juga.

Pada awalnya, kekerasan terhadap perempuan tidak dikategorikan secara spesifik sebagai kekerasan berbasis gender, juga tidak ada produk hukum yang memberi perlindungan secara spesifik bagi perempuan. Sebelum ada UUPKDRT, tindak kekerasan dalam lingkup rumah tangga ditangani dengan mengacu pada ketentuan di Kitab Undang-Undang Hukum Pidana (selanjutnya disebut KUHP),

${ }^{6}$ Pasal 2 UUPKDRT. 
yaitu penganiayaan, dan hanya terbatas pada kekerasan fisik semata, akibatnya kasus-kasus KDRT sulit diselesaikan secara hukum karena suit memenuhi unsur pidana dari penganiayaan di KUHP, sehingga kasus-kasus tersebut tidak lagi ditindaklanjuti. ${ }^{7}$ Akan tetapi, dengan lahirnya UUPKDRT, bentuk kekerasan pun diperluas dengan adanya kekerasan fisik, kekerasan psikis, kekerasan seksual, dan penelantaran. Persoalan yang tadinya bersifat pribadi pun kemudian berubah menjadi ranah publik. Selain terobosoan dalam bentuk-bentuk tindak kekerasannya, dalam hal pembuktian juga mengalami pembaharuan, yaitu korban KDRT juga berperan sebagai saksi utama dengan didukung satu alat bukti petunjuk. ${ }^{8}$ Selain itu, pengaturan mengenai hak-hak korban juga mengalami kemajuan. Salah satunya adalah hak korban untuk mendapatkan pendampingan, karena di KUHAP, tidak ada ketentuan yang mengatur bahwa korban berhak mendapatkan pendampingan.

UUPKDRT dibuat untuk mencegah, menanggulangi, dan mengurangi tindak kekerasan dan/atau kejahatan dalam keluarga, yang semakin lama semakin marak terjadi di masyarakat. Hal ini penting, karena tujuan dari membina keluarga adalah untuk mencapai keharmonisan dan kelanggengan. Sebuah rumah tangga yang bahagia dan tentram, tentunya akan menciptakan lingkungan yang aman dan kondusif, termasuk bagi tumbuh kembang anak, sehingga pemahaman dan pelaksanaan UUPKDRT adalah penting dan harus. Lahirnya UUPKDRT merupakan apresiasi bagi hak dan kedudukan perempuan dalam lingkup keluarga/rumah tangga. Penghapusan KDRT dilakukan dengan berasaskan pada penghormatan hak asasi manusia, keadilan dan kesetaraan gender, nondiskriminasi, serta perlindungan korban. Adapun tujuan dari dibentuknya UUPKDRT dirumuskan, yaitu: ${ }^{9}$

1. Mencegah segala bentuk KDRT;

\footnotetext{
${ }^{7}$ Ninik Rahayu, "Undang-Undang No. 23 Tahun 2004 tentang Penghapusan Kekerasan Dalam Rumah Tangga (UUPKDRT)”, ditjenpp.kemenkumham.go.id, diakses tanggal 26 Juni 2019.

${ }^{8}$ Pasal 55 UUPKDRT.

${ }^{9}$ Pasal 4 UUPKDRT.
} 
2. Melindungi korban KDRT;

3. Menindak pelaku KDRT; dan

4. Memelihara keutuhan rumah tangga yang harmonis dan sejahtera.

Korban KDRT yang dalam hal ini adalah pihak yang dirugikan, tentunya juga harus tetap memperjuangkan dan mempertahankan hak-haknya, agar dapat memperoleh perlindungan dan pemulihan yang layak dan memadai. Setiap korban harus menyadari bahwa mereka dilindungi oleh hukum sebagai warga negara, serta sudah layak dan sepantasnya mendapat penanganan yang cepat dan tepat, dalam rangka pemenuhan hak-haknya sebagai korban. Hak-hak korban yang tertuang dalam UUPKDRT, antara lain:

1. Korban berhak untuk mendapatkan perlindungan dari pihak keluarga, kepolisian, kejaksaan, pengadilan, advokat, lembaga sosial, atau pihak lainnya, baik secara sementara maupun berdasarkan penetapan perintah perlindungan dari pengadilan;

2. Korban berhak untuk mendapatkan pelayanan kesehatan sesuai dengan kebutuhan medis;

3. Korban berhak untuk mendapatkan penanganan secara khusu, terkait dengan kerahasiaannya;

4. Korban berhak untuk mendapatkan pendampingan oleh pekerja sosial dan bantuan hukum pada setiap tingkat proses pemeriksaan, sesuai dengan ketentuan peraturan perundang-undangan; dan

5. Korban berhak untuk mendapatkan pelayanan bimbingan rohani.

Dapat dikatakan bahwa sesungguhnya UUPKDRT merupakan suatu kebutuhan yang mendesak, mengingat masih banyaknya kasus KDRT di masyarakat yang belum mendapatkan penanganan dan perlindungan yang memadai. UUPKDRT juga merupakan suatu ketentuan yang diadakan untuk menjamin penegakan hak asasi 
manusia, terutama bagi korban yang selama ini seringkali dirugikan dalam kehidupan berumah tangga/berkeluarga. ${ }^{10}$

Secara teoritis, perlindungan hukum dibagi menjadi dua, yaitu: ${ }^{11}$

1. Perlindungan yang bersifat preventif: perlindungan hukum yang sifatnya pencegahan, yaitu sebelum terjadinya pelanggaran. Hal ini tercermin dalam peraturan perundang-undangan, dengan maksud untuk mencegah pelanggaran, serta memberi batasan-batasan mengenai apa yang seharusnya dan tidak seharusnya dilakukan.

2. Perlindungan yang bersifat represif: perlindungan hukum yang berfungsi untuk menyelesaikan permasalahan apabila terjadi sengketa. Perlindungan hukum ini merupakan perlindungan hukum terakhir, yang berupa sanksi denda, penjara, hukuman tambahan, dsb., yang baru dapat diberikan jika sudah terjadi pelanggaran.

Perlindungan preventif dalam UUPKDRT tercermin dalam rumusan mengenai perbuatan yang digolongkan sebagai tindak pidana KDRT, yang memberikan batasan mengenai hal yang tidak seharusnya dilakukan, serta pemberian perlindungan kepada korban. Sedangkan, perlindungan represif dalam UUPKDRT tercermin dalam sanksi pidana yang dikenakan terhadap pelaku yang melanggar ketentuan dalam UUPKDRT.

Dalam UUPKDRT terdapat dua bentuk perlindungan, yaitu perlindungan sementara dan perlindungan berdasarkan penetapan pengadilan. Pasal 16 UUPKDRT menyatakan bahwa perlindungan sementara adalah perlindungan yang langsung diberikan oleh kepolisian dan/atau lembaga sosial atau pihak lainnya, sebelum dikeluarkannya penetapan perintah perlindungan dari pengadilan. Sedangkan, perlindungan berdasarkan penetapan pengadilan diberikan oleh pengadilan dengan

${ }^{10}$ Ninik Rahayu, Op. Cit., diakses tanggal 26 Juni 2019.

${ }^{11}$ Sudikno Mertokusumo, Penemuan Hukum, (Bandung: Citra Aditya Bakti, 2009), hal. 38. 
surat penetapan yang berisi perintah perlindungan bagi korban dan anggoota keluarga lainnya. ${ }^{12}$ Kelebihan dari perlindungan sementara yang diberikan oleh pihak kepolisian dan/atau lembaga sosial adalah bahwa korban dapat segera diberikan perlindungan tanpa perlu menunggu penetapan pengadilan, sehingga korban dapat secara langsung dan cepat memperoleh perlindungan dan pengamanan.

Permohonan perintah perlindungan dapat diajukan oleh korban atau keluarga korban, teman korban, relawan pendamping, maupun pembimbing rohani. ${ }^{13}$ Bila permohonan perintah perlindungan tidak diajukan oleh korban sendiri, maka korban wajib memberikan persetujuan. Bila ternyata terjadi keadaan tertentu terhadap korban (misal korban dalam keadaan pingsan, kritis, dsb.), maka permohonan dapat diajukan tanpa persetujuan korban. ${ }^{14}$ Perintah perlindungan tersebut diberikan dalam jangka waktu paling lama satu tahun dan dapat diperpanjang dengan penetapan pengadilan. ${ }^{15}$

Dalam memberikan perlindungan sementara, kepolisian dapat bekerja sama dengan tenaga kesehatan, pekerja sosial, relawan pendamping, dan/atau pembimbing rohani untuk mendampingi korban. ${ }^{16}$ Dalam memberikan pelayanan kepada korban, tenaga kesehatan diharuskan untuk memeriksa kesehatan korban sesuai dengan standar profesinya, serta membuat laporan hasil pemeriksaan terhadap korban dan juga visum et repertum bila dimintakan penyidik kepolisian dan/atau surat keterangan medis lainnya, yang juga memiliki kekuatan hukum yang sama dengan alat bukti. ${ }^{17}$

Pekerja sosial, dalam memberikan pelayanan kepada korban ia harus melakukan konseling untuk menguatkan dan memberikan rasa aman bagi korban; memberi tahu korban tentang hak-haknya, agar korban dapat memperoleh perlindungan dari kepolisian dan penetapan perintah perlindungan dari pengadilan;

\footnotetext{
${ }^{12}$ Pasal 28 UUPKDRT.

${ }^{13}$ Pasal 29 UUPKDRT.

${ }^{14}$ Pasal 30 UUPKDRT.

${ }^{15}$ Pasal 32 UUPKDRT.

${ }^{16}$ Pasal 17 UUPKDRT.

${ }^{17}$ Pasal 21 UUPKDRT.
} 
mengantarkan korban ke rumah aman atau tempat tinggal alternatif lainnya; serta melakukan koordinasi dengan kepolisian, dinas sosial, atau lembaga sosial lainnya yang dibutuhkan oleh korban dalam rangka pemberian layanan kepada korban. ${ }^{18}$

Relawan pendamping, dalam memberikan pelayanan kepada korban ia harus mmeberi informasi kepada korban terkait haknya untuk mendapatkan seseorang atau beberapa pendamping; mendampingi korban di tingkat penyidikan, penuntutan, atau pemeriksaan pengadilan dengan membimbing korban, agar korban dapat menceritakan/memaparkan kekerasan yang dialaminya secara objektif dan lengkap; mendengarkan dengan empati segala hal yang dikemukakan korban sehingga korban merasa aman didampingi oleh pendamping; serta memberikan dengan aktif penguatan secara psikologis dan fisik kepada korban. ${ }^{19}$

Pembimbing rohani, dalam memberikan pelayanan kepada korban, ia harus menjelaskan mengenai hak dan kewajiban korban, serta memberikan penguatan iman dan taqwa kepada korban. ${ }^{20}$ Bagi advokat, dalam memberikan pelayanan kepada korban, ia harus memberi konsultasi hukum kepada korban yang mencakup informasi hak-hak korban serta jalannya proses peradilan; mendampingi korban di tingkat penyidikan, penuntutan, dan pemeriksaan dalam persidangan, dan membantu korban untuk menceritakan/memaparkan secara lengkap dan jelas terkait kekerasan yang dialaminya; serta melakukan koordinasi dengan sesama penegak hukum, relawan pendamping, dan pekerja sosial, agar proses peradilan dapat berjalan sebagaimana mestinya. $^{21}$

Salah satu lembaga yang berperan sebagai pelaksana pemberian perlindungan dan pemulihan bagi korban KDRT adalah Pusat Pelayanan Terpadu Pemberdayaan Perempuan dan Anak Provinsi DKI Jakarta (selanjutnya disebut P2TP2A DKI

\footnotetext{
${ }^{18}$ Pasal 22 UUPKDRT.

${ }^{19}$ Pasal 23 UUPKDRT.

${ }^{20}$ Pasal 24 UUPKDRT.

${ }^{21}$ Pasal 25 UUPKDRT.
} 
Jakarta). Pemberian perlindungan dan pemulihan bagi korban, tentunya harus mengikuti prosedur dan ketentuan yang berlaku dalam UUPKDRT. Adapun bentuk perlindungan dan pemenuhan hak-hak korban yang diberikan oleh P2TP2A DKI Jakarta kepada korban, antara lain:

1. Pendampingan dan bantuan hukum yang diberikan oleh tenaga ahli pemenuhan hak perempuan dan anak korban kekerasan, advokat, dan paralegal. Pendampingan diberikan dari tahap pemeriksaan kepolisian sampai pada tahap persidangan di pengadilan;

2. Pelayanan kesehatan yang diberikan oleh dinas kesehatan melalui rumah sakit dan puskesmas;

3. Pelayanan psikososial yang mencakup konseling, terapi, dan home visit, yang diberikan oleh psikolog, konselor, dan pekerja sosial;

4. Pelayanan rumah aman yang diberikan oleh dinas sosial; dan

5. Pemulangan dan re-integrasi yang dilakukan oleh pemda.

Dalam program kerja P2TP2A DKI Jakarta juga terdapat mitrasi cepat, yaitu program dimana tim dari P2TP2A DKI Jakarta akan langsung datang ke lokasi pada saat terjadinya KDRT. P2TP2A juga menyediakan jasa mediator bagi pasangan yang ingin melakukan mediasi, karena merupakan KDRT delik aduan, sehingga masih dapat dilakukan mediasi. Terkait dengan mediasi, banyak korban dan pasangannya yang melakukan mediasi, dan berhasil membuat mereka rujuk kembali, karena pada dasarnya, dalam diri korban sebenarnya enggan untuk melaporkan suaminya, melainkan ingin agar kekerasan tersebut dapat dihentikan. Sedangkan, dalam kasus KDRT yang melibatkan anak sebagai korban, hal itu bukan lagi delik aduan, sehingga seringan apapun bentuk kekerasannya, harus tetap diproses secara hukum. Dalam pemberian pelayanan psikologis terhadap anak, diberikan oleh psikolog khusus anak, sehingga berbeda dengan psikolog untuk perempuan dewasa. Konseling psikologis diarahkan untuk memberi pemulihan dan penguatan bagi korban. Sedangkan, pemeriksaan psikologis ditujukan untuk kepentingan pembuatan hasil pemeriksaan 
psikologis, yang merupakan rujukan dari kepolisian. Psikolog yang bertugas memeriksa dan menangani korban juga dapat diajukan sebagai saksi di pengadilan.

Dengan melihat dari bentuk perlindungan dan pemenuhan hak-hak korban yang diberikan oleh P2TP2A DKI Jakarta, dapat dikatakan bahwa pemberian perlindungan sudah sesuai dengan ketentuan yang ada dalam UUPKDRT. Dalam pemberian perlindungan dan pemenuhan hak-hak korban tersebut juga dilakukan oleh para tenaga profesional yang memang ahli di bidangnya masing-masing. Hal ini penting untuk menunjang keberhasilan pemenuhan hak-hak korban, serta memberikan penanganan yang cepat dan tepat bagi korban.

Dalam pemberian perlindungan bagi korban, baik itu yang diberikan secara represif maupun preventif, baik yang dilakukan oleh masyarakat maupun oleh pemerintah (melalui aparat penegak hukumnya), tentunya akan turut meringankan penderitaan korban, mengingat selama ini korban sudah banyak mengalami kejadian yang tidak menyenangkan. Pemberian perlindungan dan pengawasan dari berbagai ancaman yang dapat membahayakan nyawa korban sangat diperlukan. Proses pemeriksaan dan sistem peradilan yang fair terhadap pelaku kejahatan, juga merupakan salah satu upaya dalam rangka mewujudkan perlindungan bagi korban. Inilah dasar filosofis perlindungan terhadap korban dan keluarganya. ${ }^{22}$

\section{B. Pelaksanaan Perlindungan Hukum Bagi Perempuan Korban Kekerasan} Nonfisik Dalam Rumah Tangga Menurut UU No. 23 Tahun 2004 di DKI

\section{Jakarta}

Pelaksanaan adalah tindakan nyata dari suatu perencanan yang sudah disusun dan ditetapkan dengan rinci dan matang sebelumnya. Pelaksanaan dapat dilakukan, apabila segala sesuatu yang berkaitan dengannya dianggap siap sedia. Pelaksanaan juga dapat diartikan sebagai penerapan. Majone dan Wildavsky mengemukakan

\footnotetext{
${ }^{22}$ La Jamaa, "Perlindungan Korban Kekerasan Dalam Rumah Tangga Dalam Hukum Pidana Indonesia", Jurnal Cita Hukum Vol. II No. 2, Desember 2014, hal. 252.
} 
pelaksanaan sebagai evaluasi. ${ }^{23}$ SP. Siagian menyatakan bahwa jika suatu rencana sudah tersusun dan program kerjanya juga sudah dirumuskan, maka selanjutnya yang harus dilakukan adalah pelaksanaannya.

Seperti halnya juga peraturan perundang-undangan yang telah dibentuk dan diberlakukan oleh pemerintah, pelaksanaan dari peraturan perundang-undangan tersebut juga tentunya telah melalui berbagai perencanaan dan pertimbangan sebelumnya. Gagasan-gagasan berupa pemikiran hukum dibentuk dan dirumuskan dalam suatu peraturan perundang-undangan. Bahkan, mulai sejak awal pembentukannya saja, pelaksanaan dari peraturan perundang-undangan tersebut sudah harus dipikirkan dan direncanakan sedemikian rupa, agar dapat berlaku efektif dan berguna bagi masyarakat luas.

Pembentukan UUPKDRT dimaksudkan untuk mencegah, menanggulangi, dan mengurangi tindak kekrasan maupun kejahatan dalam lingkup keluarga/rumah tangga, serta memberikan perlindungan dan pemulihan bagi korban. Sejalan dengan pembentukan UUPKDRT tersebut, tentunya diperlukan pihak yang berwenang dan bertugas sebagai pelaksana, dalam rangka mewujudkan tujuan dari pembentukan UUPKDRT itu sendiri. Pada pelaksanaannya, pemberian perlindungan dan pemulihan dalam rangka pemenuhan hak-hak korban dilakukan oleh shli yang memang berkompeten di bidangnya masing-masing, agar dapat memberikan penanganan yang layak dan tepat kepada korban, sebagaimana yang diamanatkan oleh UUPKDRT.

Lewat pelayanan yang diberikan oleh tenaga kesehatan, advokat, kepolisian, pekerja sosial, relawan pendamping, dan pembimbing rohani, diharapkan agar korban dapat memperoleh penanganan yang cepat dan tepat untuk menjamin dan mewujudkan perlindungan dan pemulihan semaksimal mungkin. UUPKDRT

\footnotetext{
${ }^{23}$ Nurdin Usman, Konteks Implementasi Berbasis Kurikulum, (Bandung: CV Sinar Baru,
} 2002), hal. 70. 
mengatur mengenai hal-hal apa saja yang harus dilakukan oleh para tenaga ahli tersebut dalam membantu dan menangani kondisi dan kasus yang dialami korban.

Pada kenyataannya, pelaksanaan pemberian perlindungan bagi korban KDRT tidak selalu berjalan dengan baik dan lancar. Masih terdapat berbagai hambatan, baik hambatan dari dalam diri korban, maupun dari luar diri korban. Seringkali, perkara KDRT khususnya nonfisik tidak sampai di tingkat pengadilan. Dari segi substansi, pasal-pasal yang tercantum dalam UUPKDRT tidak memberikan keuntungan bagi korban yang mengalami kekerasan nonfisik. Berbeda halnya dengan kekerasan fisik, kekerasan nonfisik lebih sulit untuk diidentifikasi, karena untuk mendapatkan visum psichiathrium yang dikeluarkan oleh psikiater cukup lama. ${ }^{24}$ Terkadang, sulit untuk mengukur apakah korban memang benar mengalami kekerasan psikis, karena dampaknya tidak seperti kekerasan fisik yang langsung menimbulkan luka atau cacat yang dapat dilihat secara kasat mata. Kekerasan psikis harus diperiksa secara lebih lanjut dan melalui proses yang cukup panjang.

Dalam penelantaran rumah tangga, biasanya dialami oleh korban yang tidak mendapatkan nafkah secara lahir-batin. Pada kenyataannya, seringkali dalam perkara penelantaran yang dilaporkan oleh korban, tidak dapat menghadirkan pelaku dalam sidang pengadilan, karena pelaku sudah lama meninggalkan korban. Pelaku juga tidak dapat ditahan, karena sebagaimana yang tercantum dalam Pasal 21 Kitab Undang-Undang Hukum Acara Pidana (selanjutnya disebut KUHAP) yang menyatakan bahwa penahanan hanya bisa dikenakan terhadap tersangka/terdakwa yang melakukan tindak pidana dan/atau percobaan, maupun pemberian bantuan tindak pidana tersebut, apabila tindak pidana diancam dengan pidana penjara lima tahun atau lebih. Sedangkan, untuk pelaku penelantaran sebagaimana yang tercantum dalam Pasal 49 UUPKDRT hanya dikenakan tiga tahun pidana penjara. Perkara yang tidak bisa dihadirkan di persidangan, juga menyebabkan perkara tidak bisa

\footnotetext{
${ }^{24}$ Aroma Elmina Martha, Perempuan Dan Kekerasan Dalam Rumah Tangga di Indonesia dan Malaysia, (Yogyakarta: FH UII Press, 2012), hal. 51.
} 
dilanjutkan dan tidak bisa diadili secara in absentia, karena KDRT bukan pidana khusus. ${ }^{25}$ Aparat penegak hukum pun belum memiliki perspektif yang sama terkait persoalan penelantaran. Seringkali, penelantaran dipandang sebagai kondisi dimana korban sudah berkeliaran di jalan dan tidak bisa makan sama sekali. Ketika ada korban yang melapor kepada polisi, malah tidak diberikan penanganan yang lebih lanjut karena menganggap bahwa korban masih bisa hidup dan dapat dengan leluasa melaporkan kepada polisi, maka bukan sebagai penelantaran. Padahal, yang dimaksud dengan penelantaran bukan hanya secara materil, namun juga imateril, seperti tidak adanya pengasuhan dan perhatian.

Selain dari proses beracaranya, hal yang juga seringkali menjadi penghambat dalam pemberian perlindungan dan pemulihan kepada korban adalah dari segi struktur hukum, yang dalam hal ini adalah aparaturnya. Adanya perlakuan diskriminatif ketika korban melaporkan kekerasannya kepada pihak kepolisian juga menjadi kendala penanganan kasus KDRT, apalagi jika korban tidak melapor/mengadu ke unit PPA (Perlindungan Perempuan dan Anak) yang hanya ada di Polres. Seringkali, yang terjadi adalah korban melapor/mengadu kepada unit kepolisian terdekat, karena kurangnya pemahaman dan pengetahuan akan adanya unit PPA tersebut. Bahkan ada kalanya ketika pihak kepolisian malah meyudutkan korban dengan menyalahkan korban bahwa kekerasan yang dialaminya akibat dari kesalahannya, dan malah menyuruhnya untuk menyelesaikannya secara kekeluargaan saja. Dengan perspektif aparat yang cenderung tidak berpihak kepada korban membuat korban menjadi urung untuk menuntaskan persoalan kekerasan yang dialaminya lewat prosedur hukum. Berbeda halnya dengan kasus kekerasan terhadap anak, pihak kepolisian akan lebih responsif dibandingkan terhadap kekerasan terhadap perempuan dewasa.

\footnotetext{
${ }^{25}$ Ibid, hal. 71
} 
Dari segi kultur, masih ada pandangan dalam masyarakat yang cenderung menganggap bahwa persoalan keluarga/rumah tangga adalah tabu untuk dibicarakan, sehingga seolah membiarkan kekerasan itu terjadi begitu saja. Namun, hal yang paling mendasar yang menyebabkan perempuan menjadi pihak yang rentan menjadi korban dan sulit mendapatkan penanganan atas kekerasan yang dialaminya adalah adanya nilai-nilai patriarki yang masih tertanam kuat dalam masyarakat. Laki-laki dianggap sebagai sosok sentral dengan posisi yang dominan yang harus dijunjung tinggi, dan hal ini menempatkan perempuan dalam posisi yang subordinat. Laki-laki menganggap bahwa kedudukannya lebih tinggi dari pada perempuan, sehingga ketika dirinya merasa ada sedikit perlawanan dari istrinya, atau suaranya yang tidak didengarkan, maka mulailah kekerasan itu terjadi, bermula dari kekerasan psikis. Ketika kekerasan psikis tersebut tidak mampu membuat istrinya jera, maka suami mulai menghambat secara ekonomi (uang yang diberikan kepada istrinya kurang dari yang sebelumnya, atau tidak diberikan sama sekali), agar istrinya kembali tunduk kepadanya. Bila ternyata masih tidak berhasil juga, maka dimulailah kekerasan fisik. Pada intinya, laki-laki selalu ingin dirinya diakui sebagai yang berkuasa.

Adapun hal-hal dari dalam diri korban yang menghambat pemberian perlindungan dan pemulihan kepadanya, antara lain: ${ }^{26}$

1. Korban bersifat pasif, menunjukkan ketakutan dan kekhawatiran yang berlebihan (labil, banyak menangis, histeris, dsb.), bahkan sulit untuk diajak berkomunikasi dan terpaku pada pemikiran-pemikirannya sendiri. Hal ini akhirnya menyebabkan diperlukan waktu yang lama dalam proses pemberian perlindungan dan pemulihan kepada korban, karena sulit untuk meminta keterangan dan penjelasan dari korban, dan korban cenderung menutup diri. Pada saat inilah diperlukan tenaga ahli/profesional yang dapat membantu menangani kondisi korban tersebut;

\footnotetext{
${ }^{26}$ Mohammad Taufik Makarao, Weny Bukamo, dan Syaiful Azri, Hukum Perlindungan Anak dan Penghapusan Kekerasan Dalam Rumah Tangga, (Jakarta: Rineka Cipta, 2014), hal. 192.
} 
2. Korban tidak mengerti atau tidak tahu tempat mana yang harus ia datangi bila mengalami KDRT. Pusat krisis terpadu terkait kurang disosialisasikan, sehingga fungsinya belum berjalan dengan baik. Prinsip kerja dari krisis terpadu adalah dengan menerima dan menatalaksanakan korban kekerasan secara terpadu, sehingga diharapkan dapat memperkecil trauma psikis, dan luka fisik dapat segera ditangani secara profesional;

3. Korban yang mengalami trauma psikis tentunya memerlukan konseling. Akan tetapi, seringkali muncul kekhawatiran dari dalam diri korban yang akan "dicap gila" oleh masyarakat, karena pemahaman dalam masyarakat bahwa mereka yang melakukan konseling dan bertemu dengan psikolog mengalami gangguan jiwa;

4. Sikap masyarakat yang masih acuh tak acuh terkait persoalan KDRT, turut menjadi penghambat pemberian perlindungan dan pemulihan bagi korban. Tetangga, misalnya yang seringkali tidak mau ikut campur bila melihat korban mengalami kekerasan, karena merasa itu adalah persoalan rumah tangga yang bersifat pribadi, seolah membiarkan kekerasan terjadi begitu saja tanpa berniat memberikan pertolongan, atau melaporkan kepada polisi;

5. Adanya berbagai pertimbangan dalam diri korban terkait masa depannya dan masa depan anak-anaknya. Seperti, takut dirinya dan anaknya tidak dapat memperoleh nafkah untuk hidup, takut anaknya diejek/dicemooh karena memiliki ayah seorang narapidana, takut mendapatkan kekerasan yang lebih parah dari sebelumnya, dsb.

Dengan adanya lembaga/instansi yang bergerak dalam bidang pemberdayaan dan perjuangan hak-hak perempuan, diharapkan agar para perempuan yang menjadi korban namun tidak mendapatkan penanganan yang memadai dari kepolisian, dapat memperoleh pendampingan dan bantuan dari lembaga/instansi tersebut, seperti P2TP2A DKI Jakarta dan KOMNAS Perempuan, karena dalam pemberian 
perlindungan dan pemulihan kepada korban, baik P2TP2A DKI Jakarta maupun KOMNAS Perempuan berkoordinasi dan bekerja sama dengan pihak terkait lainnya.

\section{Penutup}

\section{A. Kesimpulan}

Bentuk perlindungan yang diberikan kepada korban tindak KDRT menurut UUPKDRT adalah perlindungan sementara dan perlindungan berdasarkan penetapan pengadilan. Perlindungan sementara diberikan oleh kepolisian dan/atau lembaga sosial sebelum dikeluarkan perintah penetapan perlindungan dari pengadilan. Sedangkan penatapan perlindungan pengadilan dikeluarkan berdasarkan perintah pengadilan. Perlindungan sementara merupakan suatu terobosan yang baik dan penting dalam rangka pemenuhan hak dan menjamin perlindungan bagi korban tindak KDRT. Dengan adanya perlindungan sementara, korban dapat segera diselamatkan dan menempatkan korban dalam situasi yang aman, untuk kemudian ditentukan langkah selanjutnya terkait pemberian perlindungan dan pemulihan yang tepat. Dari kedua bentuk perlindungan yang ditetapkan oleh UUPKDRT, baik itu perlindungan sementara maupun perlindungan berdasarkan ketetapan pengadilan, keduanya terwujud dalam berbagai pelayanan dan perlindungan yang diberikan oleh P2TP2A DKI Jakarta, sebagai salah satu pelaksana dari UUPKDRT selaku dinas sosial yang berwenang dan berwajib dalam memberikan pelayanan kepada perempuan korban kekerasan. Adapun bentuk perlindungan itu adalah pendampingan dan bantuan hukum yang diberikan oleh tenaga ahli pemenuhan hak perempuan dan anak korban kekerasan, mediator, advokat, dan paralegal; rujukan pelayanan kesehatan yang dilakukan oleh dinas kesehatan melalui rumah sakit dan puskesmas; pelayanan psikososial (konseling, terapi, home visit, dan re-integrasi) korban yang dilakukan psikolog, konselor, dan pekerja sosial; pelayanan rumah aman yang dilakukan oleh dinas sosial dan departemen sosial; serta pemulangan dan reintegrasi yang dilakukan oleh pemda. Pada dasarnya perlindungan yang diberikan kepada korban sesuai dengan urgensi dan kepentingan dari korban tersebut. 
Kekerasan nonfisik seringkali tidak dianggap sebagai kejahatan yang serius. Memar, luka sobek, perdarahan, dianggap lebih meyakinkan untuk dianggap sebagai suatu kejahatan. Padahal, kekerasan nonfisik juga tetap memerlukan penaganan yang tepat dan memadai. Tiap manusia tentunya memiliki kemampuan menerima tekanan yang berbeda-beda, oleh karena itu dampak kekerasan yang dialami setiao korban pun berbeda. Kekerasan nonfisik dalam rumah tangga dapat membuat korban menjadi rendah diri, malu, merasa tak berguna, mengucilkan diri dari orang-orang sekitar, sampai pada tahap yang terberat korban akan mengalami depresi. Dalam kaitannya dengan penelantaran rumah tangga, korban yang notabene tidak memiliki keahlian untuk bekerja atau malah dilarang bekerja oleh suaminya, dan akhirnya menyebabkannya sepenuhnya bergantung pada suami, akan sulit memenuhi kebutuhannya, bahkan sampai pada kebutuhan yang paling dasar sekalipun.

Pada pelaksanaannya, sesungguhnya pemberian perlindungan kepada para korban KDRT nonfisik belum terlaksana dengan baik, karena masih ada berbagai hal yang menyebabkan hambatan, baik yang datang dari dalam diri maupun luar diri korban. Terkait faktor penghambat yang datang dari dalam diri korban, tentunya diperlukan upaya dan usaha yang lebih lagi, baik dari korban, maupun dari para pihak yang memberikan pelayanan khusus untuk mengatasinya. Maka dari itu, diperlukanlah para tenaga ahli/tenaga profesional yang turut membantu dalam melayani dan mengatasi persoalan dari korban, agar bukan hanya persoalannya dapat terselesaikan dengan baik, tapi korban juga mengalami penguatan dan pemulihan untuk mengembalikannya kepada keadaan yang sedia kala. Adapun faktor penghambat di luar diri korban adalah terkait dengan prosedur pembuktian dalam kekerasan nonfisik yang seringkali menyulitkan, sehingga pada akhirnya kasus KDRT yang dialami korban tidak dapat sampai pada tahap pengadilan.

Pembuktian terhadap kasus KDRT nonfisik memerlukan waktu yang lebih lama dan melalui prosedur yang lebih sulit, mengingat kekerasan nonfisik tidak dapat 
dilihat akibatnya secara kasat mata dan langsung pada saat kekerasan itu terjadi. Kekerasan nonfisik harus melalui serangkaian tes, untuk kemudian didapatkan visum psichiatrium dari seorang psikolog. Apabila ternyata dampak dari kekerasan tersebut tidak dapat ditemukan, padahal secara nyata terjadi kekerasan, maka tetap saja kasus tersebut tidak dapat dibawa sampai ke tahap pengadilan. Bahkan, ketika korban sudah menyerahkan bukti berupa visum psichiathrium pun, pihak kepolisian masih seringkali menolak dan mempertanyakan validitasnya sebagai alat bukti.

Terkait dengan kasus penelantaran, seringkali pelaku tidak dapat dihadirkan dalam persidangan, karena memang pelaku sudah lama meninggalkan korban. Pelaku juga tidak dapat ditahan, karena menurut ketentuan dalam Pasal 21 KUHAP yang menyatakan bahwa penahanan hanya bisa dikenakan terhadap tersangka/terdakwa yang melakukan tindak pidana dan/atau percobaan, maupun pemberian bantuan tindak pidana tersebut apabila tindak pidana itu diancam dengan pidana penjara lima tahun atau lebih. Sedangkan, untuk pelaku penelantaran rumah tangga hanya dikenakan pidana penjara tiga tahun (Pasal 49 UUPKDRT). Terdakwa yang tidak bisa dihadirkan di persidangan, menyebabkan perkara tidak bisa dilanjutkan dan tidak bisa diadili secara in absentia, karena KDRT bukanlah pidana khusus. Dalam hal proses pengaduan kepada aparat penegak hukum pun, masih seringkali terjadi kendala karena adanya diskriminasi, yaitu ketika aparat tidak berpihak kepada korban, dan malah seolah menyalahkan perempuan sebagai pemicu/penyebab terjadinya KDRT, atau bahkan yang lebih parahnya lagi adalah dengan menyuruh korban untuk menyelesaikan persoalannya secara kekeluargaan.

Salah satu hal yang penting untuk diperhatikan juga adalah ketika korban sudah menyelesaikan persoalannya, lalu selanjutnya apa yang harus dilakukan korban. Terhadap korban yang pada akhirnya harus berpisah dengan suaminya dan tidak memiliki pekerjaan untuk menunjang kelanjutan hidupnya, seharusnya memperoleh suatu kursus/pelatihan untuk meningkatkan kualitas dan kemampuannya 
agar dapat mandiri dan tidak lagi bergantung pada suami. Maka, diperlukan adanya program-progran yang ditujukan untuk pemberdayaan perempuan, agar ketika persoalan KDRT-nya selesai, korban dapat berdikari dan memperoleh pendapatan untuk menghidupi dirinya dan anak-anaknya.

Hal yang disayangkan adalah minimnya data atas kekerasan dalam lingkup rumah tangga terhadap PRT. Memang benar bahwa seringkali KDRT justru terjadi terhadap istri, namun bukan berarti dalam kenyataannya PRT tidak pernah menjadi sasaran kekerasan dalam suatu keluarga/rumah tangga. Tentunya PRT juga memerlukan perhatian, mengingat ia juga sebagai subjek yang harus dilindungi dan dipenuhi hak-haknya menurut UUPKDRT.

\section{B. Saran}

Dengan adanya UUPKDRT, sesungguhnya telah memberikan payung hukum yang layak dan memadai bagi para korban. Bentuk perlindungan yang diberikan pun sudah sangat baik, terutama dengan adanya perlindungan sementara, korban dapat langsung dievakuasi dan diamankan. Hal ini merupakan suatu terobosan hukum yang sangat positif dan bermanfaat bagi korban. Akan tetapi, kendala seringkali terjadi dalam tahap pelaksanaan pemberian perlindungan tersebut.

Hal yang seharusnya diperbaiki adalah terkait dengan sistem pembuktian terhadap kasus kekerasan nonfisik yang selama ini sulit mencapai tahap pengadilan. Pembuktian juga harus melihat kenyataan bahwa kekerasan sungguh terjadi, bukan hanya dampak yang dihasilkan. Pemberian ganti rugi kepada korban juga harus dipertimbangkan untuk dimasukkan ke dalam UUPKDRT sebagai salah satu hak korban, selain perlindungan dan pemulihan, mengingat selama ini korban sudah banyak menderita atas kekerasan yang dialaminya. Selain itu, pelaku pun juga selayaknya mendapatkan konseling, agar juga terjadi perubahan dari dalam dirinya sendiri, sehingga apabila ia tahu kekerasan itu tidak wajar dan dilarang oleh hukum, ia tidak akan lagi melakukannya. PRT sebagai korban KDRT juga harus 
mendapatkan perhatian, perlindungan, serta pemenuhan hak-haknya, sebagaimana yang telah ditetapkan dalam peraturan perundang-undangan. Pada kenyataannya perempuan yang menjadi korban dalam rumah tangga/keluarga bukan hanya istri, namun dari data-data yang telah dipaparkan, lebih didominasi atas pembahasan mengenai istri sebagai korban.

Cara pandang para aparat penegak hukum juga harus diubah, agar mereka dapat melihat bahwa KDRT merupakan sebuah kejahatan yang harus ditindaklanjuti, bukan hanya menyalahkan korban dan meminta mereka untuk menyelesaikannya secara kekeluargaan saja. Diskriminasi harus diberantas dalam setiap lapisan dan golongan masyarakat, agar perempuan dapat memperoleh kedudukan yang layak dan setara dengan laki-laki, baik dalam kehidupan berkeluarga, maupun bermasyarakat.

\section{DAFTAR PUSTAKA}

\section{A. Buku}

Constanzo, Mark. Aplikasi Psikologi Dalam Sistem Hukum. (Yogyakarta: Pustaka Pelajar, 2006).

Makarao, Mohammad Taufik, Weny Bukamo, dan Syaiful Azri. Hukum Perlindungan Anak dan Penghapusan Kekerasan Dalam Rumah Tangga, Jakarta: Rineka Cipta, 2014.

Martha, Aroma Elmina. Perempuan Dan Kekerasan Dalam Rumah Tangga di Indonesia dan Malaysia. Yogyakarta: FH UII Press, 2012.

Mertokusumo, Sudikno. Penemuan Hukum. Bandung: Citra Aditya Bakti, 2009.

MS Homzah, Siti, et. al. Kekerasan Terhadap Perempuan (Tinjauan Dalam Berbagai Disiplin Ilmu dan Kasus Kekerasan). Bandung: PT. Refika Aditama, 2010.

Siagian, Sondang P. Filsafat Administrasi. Jakarta: Gunung Agung, 1985. 
Soekanto, Soerjono. Sosiologi Keluarga Tentang Ikhwal Keluarga, Remaja dan Anak. Jakarta: Rineka Cipta, 2009.

Soekanto, Soerjono dan Sri Mamudji. Penelitian Hukum Normatif (Suatu Tinjauan Singkat). Jakarta: Rajawali Pers, 2006.

Usman, Nurdin. Konteks Implementasi Berbasis Kurikulum. Bandung: CV Sinar Baru, 2002.

\section{B. Jurnal}

Jamaa, La. "Perlindungan Korban Kekerasan Dalam Rumah Tangga Dalam Hukum Pidana Indonesia”. Jurnal Cita Hukum.Vol. II No. 2 (Desember, 2014):252.

Rochaety, Nur. "Menegakkan HAM Melalui Perlindungan Hukum Bagi Perempuan Korban Kekerasan Di Indonesia”. Jurnal Studi Gender PALASTREN. Vol. 7 No. 1 (Juni 2014): 9.

\section{Website}

Rahayu, Ninik. "Undang-Undang No. 23 Tahun 2004 tentang Penghapusan Kekerasan Dalam Rumah Tangga (UUPKDRT)”. ditjenpp.kemenkumham.go.id. Diakses tanggal 26 Juni 2019. 